\title{
The Influence of Peer Pressure on Male Prisoners' Involvement in Street Crime
}

Mohd Suhaimi Mohamad, Nasrudin Subhi, Fauziah Ibrahim, Salina Nen, Norulhuda Sarnon, Ezarina Zakaria, Khadijah Alavi, Suzana Mohd Hoesni

To Link this Article: http://dx.doi.org/10.6007/IJARBSS/v11-i6/10240 DOI:10.6007/IJARBSS/v11-i6/10240

Received: 15 April 2021, Revised: 18 May 2021, Accepted: 30 May 2021

Published Online: 16 June 2021

In-Text Citation: (Mohamad et al., 2021)

To Cite this Article: Mohamad, M. S., Subhi, N., Ibrahim, F., Nen, S., Sarnon, N., Zakaria, E., Alavi, K., \& Hoesni, S. M. (2021). The Influence of Peer Pressure on Male Prisoners' Involvement in Street Crime. International Journal of Academic Research in Business and Social Sciences, 11(6), 1076-1086.

Copyright: (c) 2021 The Author(s)

Published by Human Resource Management Academic Research Society (www.hrmars.com)

This article is published under the Creative Commons Attribution (CC BY 4.0) license. Anyone may reproduce, distribute, translate and create derivative works of this article (for both commercial and non-commercial purposes), subject to full attribution to the original publication and authors. The full terms of this license may be seen at: http://creativecommons.org/licences/by/4.0/legalcode

Vol. 11, No. 6, 2021, Pg. 1076- 1086

Full Terms \& Conditions of access and use can be found at http://hrmars.com/index.php/pages/detail/publication-ethics 


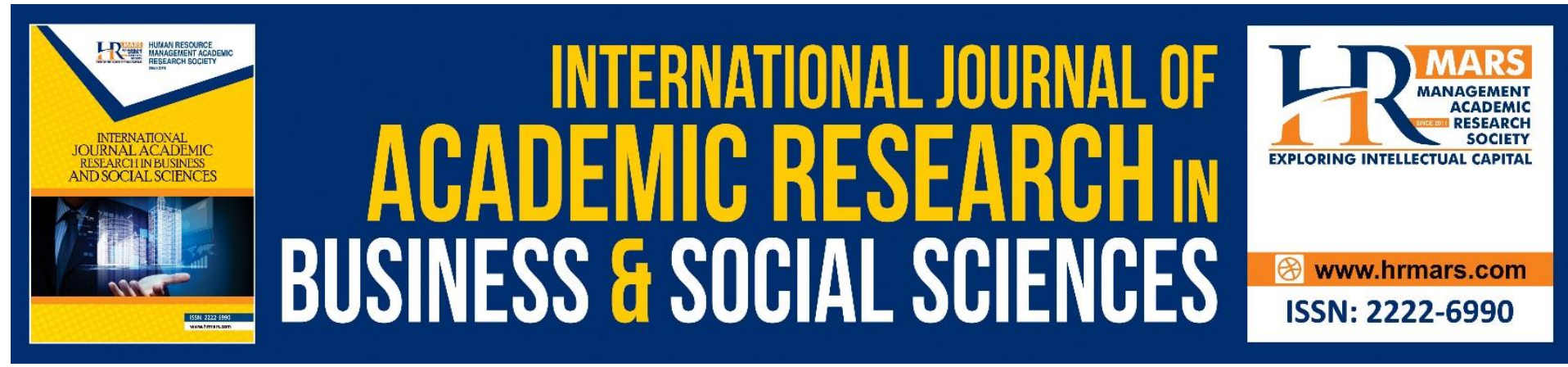

\title{
The Influence of Peer Pressure on Male Prisoners' Involvement in Street Crime
}

\author{
Mohd Suhaimi Mohamad, Nasrudin Subhi, Fauziah Ibrahim, \\ Salina Nen, Norulhuda Sarnon, Ezarina Zakaria, Khadijah \\ Alavi, Suzana Mohd Hoesni
}

Center for Research in Psychology and Human Well-Being, Faculty of Social Science and Humanities, The National University of Malaysia, 43600 Bangi, Selangor, Malaysia

Email: nas2572@ukm.edu.my

\begin{abstract}
Previous studies have indicated that peer pressure is a contributing factor to an individual's involvement in street-crime activities. This paper, thus, aims to explore the influence of peer pressure on street crime propensities among Malaysian male inmates. Employing a mixed mode research design, 282 inmates were involved in surveys at four prisons in Peninsular Malaysia. Only 20 inmates were selected for in-depth interviews at the Kajang Prison. The results show that 72 percent of prisoners admitted to having a partner involved in street crime and 60.3 percent of them engaged in criminal activity before being arrested and imprisoned. The majority of inmates admitted to set certain criteria in the selection of peers based on contextual needs - good friends to share daily activities and bad peers for criminal activities. Strategic partners (governmental bodies) need to work together strategically to ensure that street crime can be prevented at the community level.
\end{abstract}

Keywords: Street crime, Peer Pressure, Male Prisoner

\section{Introduction}

Street crime has increased in its prevalence often documented in mass media including social media, by digital or print means with a viral distribution rate. There are 35,000 street crime cases reported each year, which accounts for 17 percent of the total index crime as reported by the Royal Malaysia Police (PDRM) (2010). PDRM (2010) categorises street crime into three types, namely robbery, robbery without a firearm and gang robbery without a firearm. Presently, street-crime is the nation's second most important issue and is the main agenda under the Government Transformation Plan (GTP 1.0) to reduce crime as one of the National Productivity Areas (NKRAs). One of the causes of street crime is peer pressure (Corno, 2015) but peer factors in crime involvement remains contentious (Barlow \& Ferdinand, 1992). A peer is one of the socialising agents closest to a criminal. Peer partners play an important role in influencing an individual's involvement in criminal activity (Bolton \& Brown, 1978; Gardner et al., 1994; Nurco et al., 1998; Omboto 2013). According to Klausmerier \& Ripple (1975) peers can influence moral responsibility, courage, honesty and warmth to a greater degree extending family's influence on an individual's behaviour. Weatherburn \& Lind (2001) find 
that peer pressure plays an important role in an individual's involvement in criminal behaviour. He explained that having an influence on a partner who is a criminal would influence an individual to be involved in the crime. Omboto (2013) shows that peers often act as individuals who engage in recruitment or selection in criminal activities.

A person's inclination for a certain mode of behaviour is a complex composite of one's discipline, morals including deviant behaviour that results from a person's attachment or lack of attachment to family (Brown 2001, Fauziah et al. 2020, Nor Bayah et al. 2020; Sheau et al. 2012). Hirschi (2002) introduced the Social Control Theory explaining that individuals in a society have a dual tendency towards the dichotomy of good or bad, whereby an individual's goodness will depend on the influence of the members of a particular society. There are four elements in social control theory. which influences criminal activity, namely, 1) attachment, in which an individual is sensitive to the thoughts, feelings and wishes of another person who propels solidarity with the criminal group and promotes criminal behaviour; 2) commitments, which refer to the individual's ties to conventional subsystems such as schools, workplaces, organisations and peers; 3 ) involvement based on the activity of a person in the subsystem, where if the person is passive in the family, school or workplace then the probability of committing criminal behaviour is high; and 4) trust in social bonds, where trust in the criminal group will result in adherence to the rules of the group and will be required to comply with the criminal activities committed in the group. Social Control Theory is considered appropriate to explain the influence of peers in street crime activities in this study.

\section{Research Methodology}

This study employs a mixed method research design combining quantitative and qualitative approach. The explanatory sequential mixed method approach (Creswell \& Plano, 2007) was chosen in this study with the aim of obtaining, explaining and interpreting data in a greater breadth to capture the influence of peer pressure in street crime propensities. Quantitative data were obtained through a survey method using a set of questionnaire containing 10 sections with focus as follows: section A: demographic respondents; B: experience doing bad activities; C: modus operandi; D: drug abuse experience; E: socioeconomic factors; F: job factors; G: peer factors; H: schooling factors; I: living and neighbourhood environment factors; and J: Family factors. The Cronbach alpha value of the Peer Factor was 0.73. Qualitative data, meanwhile, is derived based on in-depth interview methods. Both data were analysed discretely but the results of the analysis were combined and recontexualised during the study discussion.

\section{Population and Samples}

In this study, population denotes street-crime prisoners who have been convicted of robbery, unarmed robbery and unarmed robbery. They are of various races and are currently undergoing sentence and rehabilitation under the control of the Malaysian Prison Department in Peninsular Malaysia. A total of 282 male inmates responded to a questionnaire about social phenomenological approaches to street crime and community-based prevention mechanisms. A total of 20 respondents from Kajang Prison were selected for in-depth interviews based on the following sample selection criteria;
i. male
ii. is currently in prison for street crime
iii. street crime offences are the final punishments for convictions 
iv. understand and able to speak in the Malay language

\section{Data Collection}

Prior to data collection, researchers had initially sought permission from the Director General of the Malaysian Prisons Department to conduct research at the selected Prison Department in Malaysia. A total of four prisons were identified in the study, Kajang Prison, Pengkalan Chepa Prison, Tapah Prison and Kluang Prison. The designated prison term is under the jurisdiction of the Director General of the Prisons Department of Malaysia and the researcher does not have the authority to choose the prison involved. After the approval letter was issued by Malaysian Prison Department, the researcher then contacted and made an appointment with each Director of Prisons involved to set a date for data collection work. Once a date has been agreed upon, the distribution of the questionnaire was subsequently carried out. After all quantitative data was collected, respondents in the Kajang Prison were selected for qualitative data collection. The selection of Kajang Prison is upon the approval of the Director General of the Prisons Department of Malaysia. All survey respondents involved in the interview session were informed of the data collection ethics and they were allowed to withdraw at any time during the interview session. Then all respondents were asked to sign the consent form acknowledging their role as a respondent. All prison data collection processes involved in this study took two months beginning in March 2014 and ending in May 2014.

\section{Data Analysis}

All quantitative data collected were analysed using the Statistical Package for the Social Sciences software version 21. Descriptive analysis was used on quantitative data. Thematic analysis was used on the qualitative data collected in this study. The interviews were recorded and transcribed verbatim and thence translated into English.

\section{Research Findings}

\section{Socio-Demographic Profile}

Table 1 shows the demographic profiles of the respondents involved in this study. According to the age group, the majority (83\%) of the prisoners involved in the study were between 19 39 years of age, followed by 16.6 percent of the prisoners aged 40-59 and only 0.4 percent were senior prisoners (60 years and above). In terms of race, as much as 69.9 per cent are Malay prisoners, prisoners followed by Indians (22\%), Chinese $(7.4 \%)$ and only 0.7 percent are Others (Bajau). When it comes to marital status, 59.9 percent of prisoners are single while 28.7 percent are married and $\mathbf{1 1 . 4}$ percent are divorced. In terms of education level, 60.3 percent of inmates had secondary education, followed by primary school of 27.3 percent, higher education of 9.2 percent and only 3.2 percent has no education background. In addition, based on work experience prior to incarceration, it is found that 45.7 percent of prisoners had permanent jobs, 37.3 percent were part-time inmates and 15.6 percent were unemployed and only 1.4 percent were students. 
Table 1: Socio-demographic Profile

\begin{tabular}{|c|c|}
\hline Category & $\begin{array}{c}\text { Frequency } \\
\text { (percentage) }\end{array}$ \\
\hline \multicolumn{2}{|l|}{ Age (years) } \\
\hline $19-39$ & 234 (83\%) \\
\hline $40-59$ & $47(16.6 \%)$ \\
\hline 60 and above & $6(0.4 \%)$ \\
\hline \multicolumn{2}{|l|}{ Race } \\
\hline Malay & 187 (69.6\%) \\
\hline Chinese & $21(7.4 \%)$ \\
\hline Indian & $62(22 \%)$ \\
\hline Others & $2(0.7 \%)$ \\
\hline \multicolumn{2}{|l|}{ Marital Status } \\
\hline Single & 169 (59.9\%) \\
\hline Married & $81(28.7 \%)$ \\
\hline Divorced & 32 (11.4\%) \\
\hline \multicolumn{2}{|l|}{ Level of Education } \\
\hline Primary school & $77(27.3 \%)$ \\
\hline Secondary school & $170(60.3 \%)$ \\
\hline Tertiary education & $26(9.2 \%)$ \\
\hline No schooling & $9(3.2 \%)$ \\
\hline \multicolumn{2}{|l|}{ Employment Status } \\
\hline Permanent jobs & $110(45.7 \%)$ \\
\hline Part-time jobs & $104(37.3 \%)$ \\
\hline Students & $4(1.4 \%)$ \\
\hline No jobs & $44(15.6 \%)$ \\
\hline
\end{tabular}

\section{Peer Pressure Factor}

In this study, peers refer to the relationship between the inmate and his partner with an engagement in activities that bear influence and respondents' motivation towards committing street crime. The findings of the study show that peer influence plays an important role as a driving factor for respondents to be involved in street crime activities in Malaysia. Table 2 shows that the majority (72 percent) of the respondents involved in this 
study admitted that they had a lot of friends who are involved in street crime activities (item 1). In fact, they also acknowledged that most of them (60.3 percent) often engaged in criminal activities with their friends (item 2 ) and admitted were involved in street gang activities (58.6 percent) (item 3).

In terms of peer relations, the study found that the majority of respondents (72 percent) acknowledged and regarded friends as the person they were closest to (item 4). This close relationship made most of them (53.6 percent) feel more comfortable sharing problems with friends than with their own family members (item 5 ). Although they had a close relationship with their peers, the study found that most (57.1 percent) friends involved in crime did not help them when they were in trouble (item 6). Based on peer pressure, the study found that most respondents who engaged in street crime activities admitted that they were easily influenced by their peers' behaviour (item 7). 61.7 per cent of them agreed and strongly agreed with the statement saying that friends often influenced themselves to engage in criminal activity (item 8) and 59.9 per cent of them acknowledged that their friends were individuals who taught people how to do crime against society (item 9).

Table 2: Peer Pressure Items

\begin{tabular}{|c|c|c|c|c|c|}
\hline No. & Item & $\begin{array}{c}\text { Totally } \\
\text { not agree } \\
(\%)\end{array}$ & $\begin{array}{l}\text { Not agree } \\
(\%)\end{array}$ & $\begin{array}{l}\text { Agree } \\
(\%)\end{array}$ & $\begin{array}{c}\text { Totally } \\
\text { agree } \\
(\%)\end{array}$ \\
\hline 1. & $\begin{array}{l}\text { I hang out with friends who are } \\
\text { involved in crime }\end{array}$ & 5.0 & 23.0 & 48.2 & 23.8 \\
\hline 2. & $\begin{array}{l}\text { I often do criminal activities with } \\
\text { friends }\end{array}$ & 9.9 & 29.8 & 42.2 & 18.1 \\
\hline 3. & $\begin{array}{l}\text { I have never been involved with any } \\
\text { crime group }\end{array}$ & 15.6 & 42.9 & 30.1 & 11.3 \\
\hline 4. & $\begin{array}{l}\text { Friends are the people who are closest } \\
\text { to me }\end{array}$ & 8.5 & 19.5 & 54.3 & 17.7 \\
\hline 5. & $\begin{array}{l}\text { I'm more comfortable sharing } \\
\text { problems with friends than family }\end{array}$ & 10.3 & 36.2 & 36.9 & 16.7 \\
\hline 7. & $\begin{array}{l}\text { Friends who involved in crime will help } \\
\text { me when I'm in trouble }\end{array}$ & 22.0 & 35.1 & 31.9 & 11.0 \\
\hline 8. & $\begin{array}{l}\text { I am easily influenced by my friend's } \\
\text { behavior }\end{array}$ & 7.8 & 34.0 & 44.0 & 14.2 \\
\hline 9. & $\begin{array}{l}\text { Friends often influence me to commit } \\
\text { crimes }\end{array}$ & 9.9 & 28.4 & 48.6 & 13.1 \\
\hline 10. & $\begin{array}{l}\text { A friend taught me how to commit a } \\
\text { crime }\end{array}$ & 12.1 & 28.0 & 44.3 & 15.6 \\
\hline 11. & I need a friend support to get better & 7.8 & 14.5 & 40.4 & 37.2 \\
\hline
\end{tabular}


12. A friend once advised me to quit criminal activities

13. I need the support of a friend to leave criminal activity
6.0

16.0

50.0

28.0

6.4

10.3

44.3

39.0

$N=282$

Given that peer pressure has a very strong influence on respondents to be involved in street crime activities, it is evident that the motivation to leave criminal activity is concentrated among their peers as a driving force behind criminal activity. The survey found that $\mathbf{7 7 . 6}$ per cent of respondents admitted that they needed peer support to become better people (item 11). 78 per cent of respondents also admitted that their friends had advised them to quit their criminal activities (item 12) and a majority of 83.3 per cent of them admitted that they needed peer support to leave street crime activities. they did (item 13).

\section{Characteristics of Peer}

The majority of respondents found that they had peers who were about the same age as them. However, there are also respondents who are friends with criminals who are older than them. Based on the analysis of the study's data, a criminal has characteristics of peer selection. Most criminals choose their peers based on context or situation. Usually criminals spend a lot of time with good friends but only do criminal activities with friends who do not live at home. Most criminals interviewed stated that they chose criminals based on behaviours that were similar to their own; "Yes it is more like that because he is a person but I like to see him have a personality, his temperament is not hot tempered, who does not like to fight and is ok" (Respondent 1). This statement was also acknowledged by other criminal associates; "He's all right, no problem, he's a man, we have same mind" (Respondent 20).

There are also respondents who admitted to choosing a partner who was already married. This is because married people have the urge to commit crimes in order to meet the needs of their families. Although their intentions are good but their actions do not justify the means. For example, respondent 1 exemplify;

He's a guy like me too, he's a career man because he is a man, a family, sometimes a double-minded but heck of a drug, but depending on the pay alone is not enough for two or one child ... want to buy milk, to buy diapers (Respondent 1).

However, some criminals only have partners before they get married. This may be because when they are not married it is easier to spend time with friends. This is not the case post marriage where time is mostly spent with family; "I used to have a lot of friends but after I got married ... I didn't go with friends ... I went to the same house ... I am the only one now ... I used to have 3 people ... married already because I don't like friends because I don't have friends" (Respondent 5). The same view is shared by other inmates who also have peers who work in the same place before marriage; "I don't like friends ... I have friends but less ... even air-condition work ... I like friends who don't want to talk much, please help, I like that, talk more of useless ... but that's my unmarried time I know him" (Respondent 6).

In addition, some criminals admit to having peers who work in the same place as them. They claim their colleagues to be helpful and unselfish. For example, respondents 11 and 17 exemplify this; 
My co-worker ... yes he is, he is good, he is ok ... home is not close to one side but one department ... he is ok, for good opinion and advice ... I like to find friends who are not important to himself, that's one of them (Respondent 11).

Further to the nuance of crime peer selection, some criminals thought a good partner is a roommate. This may be because their neighbours have known them since childhood and have been the place to express their feelings or to ask for help when in need; "Remember, [his] memories of childhood friends but [he] never went to school, he was a friend of [the] village, many a year at one time [want] the desert ... want [to] steal" (Respondent 7). While one respondent also acknowledged that his best friend was a neighbour and he is now his wife; "My childhood, my school days with a close friend ... a village ... he can understand my heart, he helps me a lot, even in school he helps me, please write" (Respondent 16). In addition, there were respondents who admitted that their partner was also a criminal and had never been arrested; "There was a good friend ... she was married but she was divorced ... she was married ... about one village was from a little [neighbour's friend] ... she took [drugs] too" (Respondent 19). However, one criminal who stated that he committed a crime with a friend who did not know him, a friend who was not living at home or was not a colleague or neighbour; "This is a jealous friend, most of the outsider is not a neighbour ... it is an outsider because he is one of my gangs" (Respondent 1).

\section{Activities with Peer}

The majority of criminals have different views of their peers in a binary view of the ideal partner as the good friend and the criminal partner as the bad friend. There are respondents who do activities such as cooking, fishing, watching television and watching football with their best friends;

The most exciting time for me is when it is time to cook always the same. Brother is the one who always cooks. That's when you ask what kind of work you do, sometimes go fishing early in the morning ... even if you don't go fishing, we do go to watch television, and then we do ... like me while having a little fun, like shabu but isn't bad at all, we also do not do house chores? (Respondent 3).

Another respondent admitted to having a peer who was not a good friend to hang out at a coffee shop and watch football; "There are friends but good friends are not there, just coffee shop friends, watch football matches' while in coffee shop, eating bread alone" (Respondent 13). Most criminals admit that they were involved in negative activities with their friends. Among the activities carried out with peers are gambling, drug abuse, robbery, stalking and motorcycle theft. For example, respondent 4 admitted that he had a partner who was involved in gambling. Many previous studies support that negative peer activity will perpetuate an individual to committing crimes (Bolton \& Brown 1978; Gardner et al., 1994; Nurco et al., 1998; Sheau et al. 2011; Tharshini et al. 2016). In addition, other respondents also acknowledged that they were doing negative activities with their peers;

We ride motorcycles together, I start to know him when I have my own motorcycle, know that negative activity, when I need money to modify my motorcycles, we will go anywhere to find motorcycle's parts even to Negeri Sembilan, we steal motorcycles, divide into small parts and deliver it to Terengganu ... near Pahang area, in 2009 we 
steal motorcycle here and we sell it near Pahang because over there are higher prices (Respondent 8).

Often peers involved in criminal activities also influence the daily activities of criminals; "Some are ok, some are not, only three people are good, times are hard to help, that's bad usually, after taking drugs they follow people to steal projects" (Respondent 9). In contrast, respondents indicated that they were engaged in the activities of friends because they were helpful; "He came here to work, to work chicken [to be a pimp], he used to work in a pub, I knew him very well, he always helped me, I called him, he was in Thailand and he banked with me" (Respondent 10). In addition, there are criminals who acknowledge that their peers are simply close to their families in running errands;

He was a normal person coming to my house, he was a close friend to my mom, and my mom considered him a kid too, whatever my mom told me to ask for a look at my younger sister what school, sometimes my mom wants to go here and no one wants to take her, my sister works, and even gives me a motor home, bring a car to get my mom (Respondent 8).

This finding is supported by a study by Kakar (2005) who found that individuals who are involved in criminal activities have friends who are close to the family. There are also criminals who follow friends into negative activities when they have confidence and categorise friends based on their experiences;

He's the one who comes to my house, let's go to work together. I'm sure I'm just following, I have three types of friends - good friends who really support me, friends who have time for me, and bad friends who really need work for money. (Respondent 12).

\section{Conclusion and Recommendation}

From this study, peers have an indirect influence on street crime involvement among male prisoners involved in this study. This clearly shows that qualitative data explains that peer selection criteria are objective in that they distinguish good friends from good activities and bad ones from street crime activities. Aspects of trust in long-term peers such as co-workers make prisoners vulnerable to criminal activity for the first time and eventually feel comfortable doing street crime in groups. However, peer-to-peer relationships are not straightforward because their acquaintances with peers are long-term and non-criminal. It is also possible that a peer's negative influence on street crime is not solely due to friends but other social environmental factors. However, the majority of the inmates admitted to not committing solitary street crime and that it was closely related to their relationship with their peers. Therefore, preventive mechanisms involving strategic partners such as the Malaysian Prison Department, Ministry of Home Affairs, Ministry of Youth and Sports, Royal Malaysian Police are important. All parties need to develop community-based programs so that the community, especially the youth, are more likely to be involved in street crime so that they can be given the knowledge and skills of being involved in choosing a smart and moral peer who is civic minded has a mature sense of decorum. If all these strategic parties are aware of and play their role in society, the occurrence of street crime can be greatly reduced and thus improve the well-being of the community. 


\section{Acknowledgement}

This study has been supported and funded by the Ministry of Higher Education of Malaysia through the Exploration Research Grant (ERGS) grant code: ERGS/1/2013/SSO3/ UKM/02/1. Acknowledgments are also addressed to the Faculty of Social Sciences and Humanities, UKM, the Prison Department of Malaysia and all those involved in the completion of this study.

\section{References}

Barlow, H. D., \& Ferdinand, T. N. (1992). Understanding delinquency. New York, NY: HarperCollins.

Bolton, W. D., \& Brown, D. W. (1978). Rural juvenile delinquency: Problems \& needs in East Tennessee. AgResearch Bulletins, 580, 1-48.

Brown, D. K. (2001). Street crime, corporate crime, and the contingency of criminal liability. University of Pennsylvania Law Review, 149(5), 1295-1360.

Corno, L. (2015). Homelessness and crime: Do your friends matter? The Economic Journal, 127(602), 959-995.

Creswell, J. W., \& Plano, C. V. L. (2007). Designing and conducting mixed methods research. Thousand Oaks, Calif.: SAGE Publications

Fauziah, I., Suzana, M. H., Ezarina, Z., Salina, N., Norulhuda, S., Khadijah, A., Nasrudin, S., \& Mohd Suhaimi M. (2020). Drug abuse and the involvement of prisoners in street crimes. International Journal of Psychosocial Rehabilitation, 24(4), 4508-4516.

Gardner, B. (1994). Successful Pennsylvania school probation expands. Corrections Compendium, 19(8), 1-3.

Hirschi, T. (2002). Causes of delinquency. New Brunswick, N.J.: Transaction Publishers.

Kakar, S. (2005). Geng membership, delinquent friends and criminal family members: Determining the connections. Journal of Gang Research, 13(1): 41-52.

Klausmerier, H. J., \& Ripple, R. E. (1975). Learning and human abilities: Educational psychology. New York: Harpwe \& Row.

NorBayah, A. K., NurSaadah, M. A., Norhayati, I., Hilwa, A., \& NorDiana, J. (2020). Do friendship attachment and positive and negative emotions encourage emotion prosocial behavior among adolescents in Malaysia? International Journal of Psychosocial Rehabilitation, 24(4), 4410-4423.

Nurco, D. N., Kinlock, T. W., O'Grady, K. E., \& Hanlon, T. E. (1998). Differential contributions of family and peer factors to the etiology of narcotic addiction. Drug and Alcohol Dependence, 51(3), 229-237.

Omboto, J. (2013). Challenges facing the control of drugs and substance abuse in prisons. Saarbrücken: LAP LAMBERT Academic Publishing.

Chong, S. T., Farquharson, K. Er, A. C., Lukman, M. Z., \& Mokhtar, M. K. (2011). Enhancing youth civic engagement and generalized trust through bonding social capital among friends. Pertanika of Journal of Social Sciences and Humanities, 19(S), 57-64.

Chong, S. T., Jaafar, J. S., Rahim, A. S., Kadir, N. B. A., Subhi, N., Koh, D., Khairuddin, L. L., \& Nen, S. (2012). Self-integrity as the protective shield for peer group loitering among atrisk youth. Asian Social Science, 8(9), 98-102.

Royal Malaysia Police. (2010). Laporan Tahunan Polis Di-Raja Malaysia 2009. Kuala Lumpur: Royal Malaysian Police.

Tharshini, N. S., Ibrahim, F., Mohamad, M. S., \& Zakaria, E. (2016). Socio-demographic and perpetrators experience in committing crime: A descriptive study on male young 
INTERNATIONAL JOURNAL OF ACADEMIC RESEARCH IN BUSINESS AND SOCIAL SCIENCES

Vol. 11, No. 6, 2021, E-ISSN: 2222-6990 @ 2021 HRMARS

offenders undergoing community service order. Journal of Advanced Research in Social and Behavioural Sciences, 4(1), 7-18.

Weatherburn, D. J., \& Lind, B. (2001). Delinquent-prone communities. Cambridge, UK: Cambridge University Press. 